\title{
Creative thinking ability and cognitive knowledge: Big Five personality
}

\author{
${ }^{* 1}$ Jonni Sitorus; ${ }^{2}$ Nirwana Anas; ${ }^{3}$ Ermaliana Waruhu \\ ${ }^{1}$ Badan Penelitian dan Pengembangan Provinsi Sumatera Utara \\ Jl. Sisingamangaraja No.198, Siti Rejo I, Kota Medan, Sumatera Utara 20216, Indonesia \\ ${ }^{2}$ Faculty of Tarbiyah Science and Teacher Training, Universitas Islam Negeri Sumatera Utara \\ Jl. William Iskandar Ps. V, Kenangan Baru, Kab. Deli Serdang, Sumatera Utara 20371, Indonesia \\ ${ }^{3}$ Sekolah Dasar Negeri 014648 Padang Mahondang \\ Padang Mahondang, Pulau Rakyat, Kabupaten Asahan, Sumatera Utara 21273, Indonesia \\ ${ }^{*}$ Corresponding Author. E-mail: sitorus_jonni@yahoo.co.id
}

Submitted: 04 January 2019 | Revised: 27 May 2019 | Accepted: 05 August 2019

\begin{abstract}
This research aims at describing the ability and level of student's creative thinking and student's cognitive knowledge. It is qualitative research to search for data and information. Operationally, this research was conducted with some steps namely: (1) giving a set of big five personality test to 215 students to determine their personality type, (2) giving a set of creative thinking test of 215 students to measure the ability and level of their creative thinking, and (3) choosing one student randomly from each student's personality type to be interviewed to search their cognitive knowledge. The results show that every student has a creative thinking ability, but the level of creative thinking varies. The category of student's creative thinking ability based on Big Five Personalities is 'moderate or high'. The level of student's creative thinking based on the big five personality is 'very creative, creative, quite creative or less creative'. The student's cognitive knowledge based on the big five personality is drawing, designing, ascertaining, dividing, reasoning, analogy, imagining, utilizing, solving, understanding, determining, mentioning, and using trial and error.
\end{abstract}

Keywords: creative thinking ability, cognitive knowledge, Big Five personality, creative thinking level, novel answer

Permalink/DOI: https://doi.org/10.21831/reid.v5i2.22848

\section{Introduction}

Creativity is not only a result but can also blossom other cognitive functions, such as cognitive thinking (Silvia, 2008). Most of the cognitive theory models focus on the ability to think and solve problems creatively. The cognitive theory model provides a place for psychometric procedures to understand various cognitive abilities, including creative thinking ability (Batey \& Furnham, 2006).

Creative thinking is the process of understanding difficulty, problem, information gaps, loose elements, and inconsistency; formulating the problem clearly; supposing or formulating hypotheses about deficiency; examining the hypotheses and possibilities of revising and re-examining or redefining the problem, and ultimately communicating the results. Creative thinking is an individual ability based on its uniqueness to generate worth and novel ideas. The formulation of creativity that emphasizes creative thinking ability is known as the major impetus for the research of creativity (Santrock, 2003).

The ability to think creatively is closely related to intelligence abilities or cognitive traits (Setiawan, 2016). Cognitive traits include fluency, flexibility, originality, elaboration, and also many affective traits (Setiawan, 2017; Wolfradt \& Pretz, 2001): curiosity, courage to take risks, challenged by plurality, and imagi- 
native. The primary aptitude traits which are related to creativity, and typically called the characteristics of creative thinking ability (Carson, Peterson, \& Higgins, 2005), namely: sensitivity to problems; fluency, includes the fluency of word, expressional, and ideational; flexibility, includes the spontaneous and adaptive flexibility; originality; elaboration; and redefinition. Creativity as an associative function is the ability to connect the objects, experiences, knowledge, and prior information to something new (Mumford, 2003).

Batey, Furnham, and Safiullina (2010) state that there is a positive and negative relationship between creativity with the dimensions of the Big Five personality. Creativity is positively correlated with extraversion and openness dimensions and is negatively related to agreeableness, conscientiousness, and neuroticism. Individuals with an openness dimension have creative characteristics, broad interests, curious, original, and imaginative. Neuroticism has an anxious, nervous, emotional, insecure, and incompetent dimension.

\section{Creative Thinking Ability}

Creative thinking is a process of constructing ideas to gain something new in insights, approach, perspective or way of understanding the problem (Grieshober, 2004; Isaksen, Dorval, \& Treffinger, 2000; Martin, 2009; McGregor, 2007). Some indicators of creative thinking are fluency, flexibility, novelty, productivity, impact, success, efficiency, coherence (Briggs \& Davis, 2008; Martin, 2009; Santrock, 2007; Sternberg, 2012). Creative thinking is a combination of logical and divergent thinking based on intuition consciousness by caring for fluency, flexibility, and novelty (Pehkonen \& Törner, 2004; Siswono, 2004).

Everyone has the potential to think creatively, but the level of creative thinking for each person is different (Alenikov, 2002; Neethling, 2000). Siswono (2004) classifies five creative thinking levels: level 4 (very creative), the student can solve the problem by finding more than one novel solution; level 3 (creative), the student can solve the problem by only finding one novel solution; level 2 (quite creative), the student can solve the problem by finding more than one flexible solution; level 1 (less creative), the student can solve the problem by only finding one flexible solution; and level 0 (not creative), the student is unable to solve the problem.

Fluency traits include sparking many ideas, answers, problem-solving, or questions fluently, providing many ways or suggestions for doing things, and always think of more than one answer. The flexibility traits include generating various ideas, answers, or questions, being able to see a problem from different perspectives, searching for many different alternatives or directions, and being able to change the approach or way of thinking. The originality traits include generating something new and unique, thinking of unconventional ways to express oneself, and being able to make unusual combinations of parts or elements.

Novelty is not idea really new, but new for the student (Briggs \& Davis, 2008). The novelty concept must be returned to the student's knowledge condition and cannot be generalized to all conditions. Choi (2004) informs that novelty relates to a new experience, where the novelty level is an incompatibility function between the past and the present experience. The novelty of the concept of problem-solving is the student's ability to solve problems by giving several different and correct answers or one unusual answer, which is adjusted to student's knowledge level. Different answer refers to the answer looks different and does not follow a certain pattern.

\section{Big Five Personality}

Personality is a dynamic organization or composition from the psychophysical system as unique individual characteristics (feeling, thought, behavior, physical, intelligence, or mood), settled at someone to adjust to the environment (Feist \& Feist, 2006).

One of the approaches to measure psychology personality type is the Big Five Personality, which has five personality dimensions, namely: extraversion, agreeableness, conscientiousness, neuroticism, and openness (Friedman \& Schustack, 2008). Raymond B.

86 - Copyright (C) 2019, REiD (Research and Evaluation in Education), 5(2), 2019 ISSN 2460-6995 
Cattell is a first theorist in measuring the personality, which is then developed into the basic form of personality structure, better known as the Big Five Personality nowadays.

The characteristics of the Big Five Personality are: (1) extraversion, a high-score individual tends to be full of affection, cheerful, talkative, gregarious, and loving. Conversely, a low-score individual tends to be self-contained, quiet, passive, and lack the ability to express feeling; (2) agreeableness; a high-score individual tends to have full trust, generous, receptive and kind-hearted. A low-score individual tends to be suspicious, stingy, unfriendly, irritable, more aggressive, critics, and less cooperative; (3) conscientiousness, a highscore individual tends to be hardworking, meticulous, timely, and diligent. A low-score individual tends to be irregular, lax, lazy, aimless, and easily give up when getting difficulty; (4) neuroticism, a high-score individual tends to be anxious, temperamental, self-pitying, self-aware, emotional, and prone to stress disorders. A low-score individual tends to be happier and content, calm, ordinary, self-satisfied, and unemotional; (5) openness, refers to how individual to adjust oneself to a new situation and idea. A high-score individual tends to be easy to tolerate and absorb information, focus, and be alert to feeling, thought, and impulsivity. A low-score individual tends to be narrow-minded, conservative, and does not like change.

Batey et al. (2010) state that there are positive and negative linkages between creativity and the dimension of the Big Five personality. Creativity is positively associated with extraversion and openness dimensions and is negatively related to agreeableness, conscientiousness, and neuroticism.

\section{Cognitive Knowledge}

Anderson et al. (2001) state that cognitive taxonomy as a revision of Bloom's Taxonomy refers to memorizing, that is recognizing and recalling; understanding, that is interpreting, exemplifying, classifying, summarizing, comparing and explaining; applying, that is executing and implementing; analyzing, that is differentiating, organizing and attribut- ing; evaluating, that is checking and critique; and creating, that is generating, planning, and producing (Krathwohl, 2002; Smith, 2008).

Moreover, de Lange (2003) asserts that student's cognitive knowledge in the process of mathematics learning is to produce great ideas to solve the mathematical problems; create a mathematical model created by students to solve problems of student's learning creativity; bring up various problem solving; express ideas; connect the mathematics concepts with everyday life; and use mathematics and mathematical mindset in everyday life in various sciences through the practice of acting and mathematical activities on the basis of logical, rational, critical, creative, accurate, honest, effective and efficient.

According to Galbraith and Stillman (Ee \& Widjaja, 2013; Stillman, 2015), students' cognitive knowledge when given the problems are to understand and structuralize the problems; simplify and interpret the context; assume, formulate and perform the mathematization process; verify the results by comparing, critique, validating, communicating (Rahayu (2015), justifying, and report on writing; and revise the incorrect answer based on the revision results.

\section{Method}

This study is qualitative research. The researchers used the basic statistics (mean \& percentage) to get the student's creative thinking ability data and then interviewed some students to get the student's cognitive knowledge data. The research was conducted in March 2017 for seven primary schools in North Sumatra Province, Indonesia.

\section{Population and Sample}

The number of research population is 611 sixth class students from seven primary schools in North Sumatra Province. The number of research samples is 215 students chosen randomly, a minimum of $10 \%$ of the population (Cohen, Manion, \& Morrison, 2007). The sample consists of 98 female students and 117 male students. They are around 12-13 years old. 
Research Instrument and Data Collection Technique

Data were collected in two ways, namely: test and in-depth interview. The research instruments are a set of creative thinking tests, big five personality test, and interview guidelines. The researchers used the standard Big Five Personality test and creative thinking test, so they do not need to be validated. The creative thinking test consists of an openended and problem-solving item focused on two-dimensional figure material in class VI of primary school for measuring the ability and level of student's creative thinking. The Big Five personality test was used for determining student's personality type. The interview guideline was used for searching student's cognitive knowledge.

\section{Data Analysis Technique}

Qualitative and quantitative data were analyzed qualitatively by some phases, namely: coding each data and information obtained from interviews and tests; determining the similarity of data and information obtained from interviews and tests based on different contexts; collaborating on differences in data and information obtained from interviews and tests; classifying and categorizing data and information obtained from interviews and tests, and looking for relationships between each categorization

\section{Research Procedure}

First, the researchers gave a set of big five personality test (Mayer, 2003, 2005) to 215 students to determine their personality type. The results are presented in Table 1.
Second, the researchers gave a set of creative thinking tests of 215 students to measure the ability and level of their creative thinking. The creative thinking ability is measured from student's answer fluency. The researchers gave the score of creative thinking ability without differentiating the creative thinking indicator. The score of one correct answer is 1, two correct answers are 2, and so on. The researchers then converted the score of value to categorize the student's creative thinking ability based on 'scale 5', namely: very low (0-54), low (>54-64), moderate $(>64-79)$, high (>79-89) and very high $(>89$ 100). The creative thinking level is measured from student's answer flexibility and novelty. According to Siswono (2004), the creative thinking level is categorized into five, namely: level 4 (very creative), student is able to solve the problem by giving more than one novel answer; level 3 (creative), student is able to solve the problem by only giving one novel answer; level 2 (quite creative), student is able to solve the problem by giving more than one flexible answer; level 1 (less creative), student is able to solve the problem by only giving one flexible answer; and level 0 (not creative), student is unable to solve the problem.

Third, the researchers chose one student randomly from each student's personality type, as shown in Table 1, as a key informant in this research to be interviewed to search their cognitive knowledge. The six students as research informants must have a creative thinking level 'very creative or creative'. The researchers interviewed them by using exploratory and confirmatory approaches.

Table 1. Student's personality type based on big five personality

\begin{tabular}{clcc}
\hline No. & Trends of Student's Personality Type & $\begin{array}{c}\text { Number of Student } \\
\text { (Person) }\end{array}$ & Percentage (\%) \\
\hline 1. & Extraversion & 28 & 13.02 \\
2. & Agreeableness & 21 & 9.77 \\
3. & Extraversion + agreeableness + openness & 53 & 24.65 \\
4. & Extraversion + conscientiousness + openness & 48 & 22.33 \\
5. & Extraversion + neoroticism + openness & 41 & 19.07 \\
6. & Agreeableness + openness & 24 & 11.16 \\
& Total & 215 & 100 \\
\hline
\end{tabular}

88 - Copyright (C) 2019, REiD (Research and Evaluation in Education), 5(2), 2019 


\section{Findings and Discussion}

Findings

Student's creative thinking ability based on the Big Five personality is shown in Table 2 , in which, student's creative thinking ability with personality types of extraversion, agreeableness, or extraversion + neuroticism + openness is under overall mean value (75.50).
Student's creative thinking ability that has personality types of extraversion + agreeableness + openness, extraversion + conscientiousness + openness, or agreeableness + openness is over the overall mean value (75.50). The mean difference of student's creative thinking ability for each personality type is shown in Table 3 . Student's creative thinking level based on the Big Five personality can be seen in Table 4.

Table 2. Student's creative thinking ability based on big five personality

\begin{tabular}{clcc}
\hline No. & Trends of Student's Personality Type & Mean Value & Category of Creative Thinking Ability \\
\hline 1. & Extraversion & 65.82 & Moderate \\
2. & Agreeableness & 70.04 & Moderate \\
3. & Extraversion + agreeableness + openness & 83.73 & High \\
4. & Extraversion + conscientiousness + openness & 78.66 & Moderate \\
5. & Agreeableness + openness & 80.51 & High \\
6. & Extraversion + neoroticism + openness & 74.22 & Moderate \\
& Overall mean value & 75.50 & Moderate \\
\hline
\end{tabular}

Table 3. Mean difference in student's creative thinking ability for each personality type trend

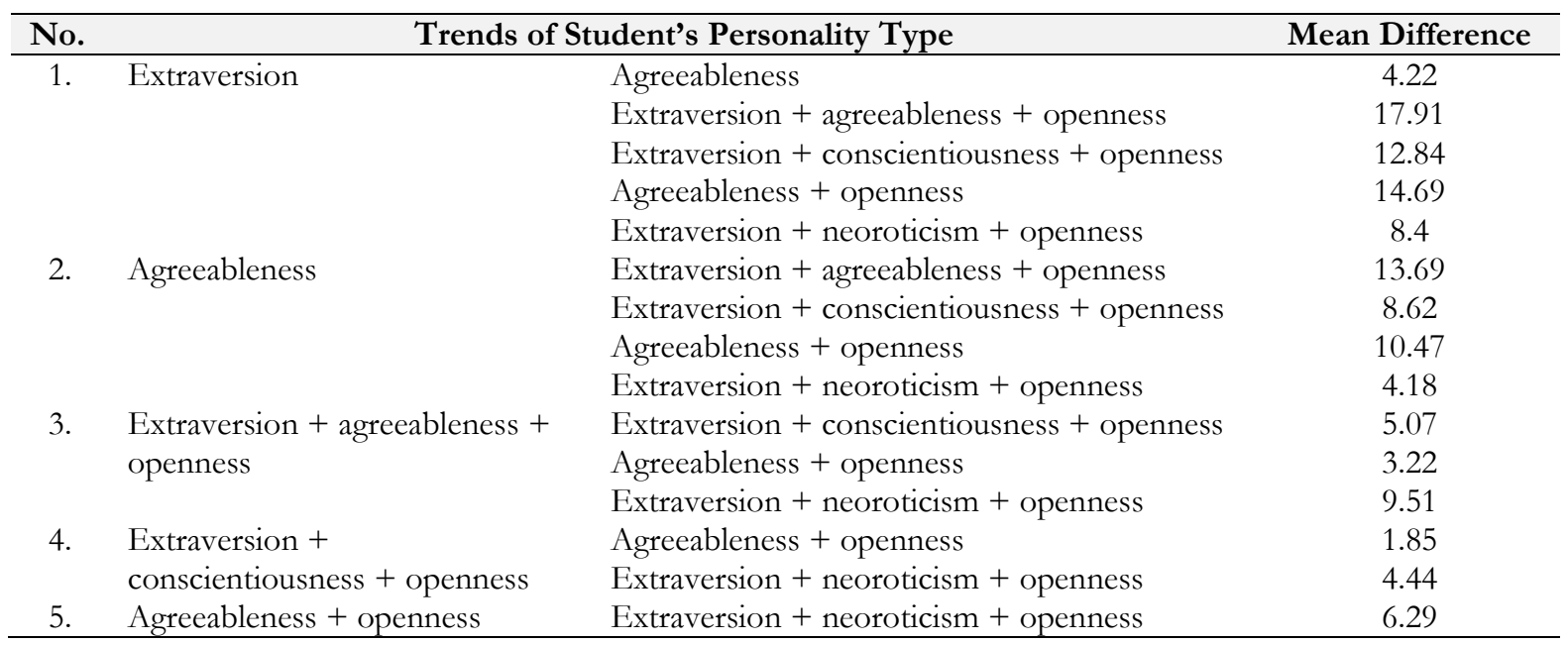

Table 4. The number of student based on creative thinking level

\begin{tabular}{|c|c|c|c|c|c|c|c|}
\hline \multirow[b]{2}{*}{ No. } & \multirow[b]{2}{*}{$\begin{array}{l}\text { Trends of Student's } \\
\text { Personality Type }\end{array}$} & \multicolumn{5}{|c|}{$\begin{array}{l}\text { The Number of Student based on Creative Thinking Level } \\
\text { (Person) }\end{array}$} & \multirow[b]{2}{*}{ Total } \\
\hline & & $\begin{array}{c}\text { Level } 4 \\
\text { (>1 novel } \\
\text { answer) }\end{array}$ & $\begin{array}{c}\text { Level } 3 \\
\text { (1 novel } \\
\text { answer) }\end{array}$ & $\begin{array}{c}\text { Level } 2 \\
\text { (> } 1 \text { flexible } \\
\text { answer) }\end{array}$ & $\begin{array}{c}\text { Level } 1 \\
\text { (1 flexible } \\
\text { answer) }\end{array}$ & $\begin{array}{c}\text { Level } \\
0 \\
\text { (none) }\end{array}$ & \\
\hline 1. & Extraversion & 6 & 18 & 3 & 1 & - & 28 \\
\hline 2. & Agreeableness & 3 & 12 & 4 & 2 & - & 21 \\
\hline 3. & $\begin{array}{l}\text { Extraversion }+ \text { agreeableness } \\
+ \text { openness }\end{array}$ & 20 & 15 & 18 & - & - & 53 \\
\hline 4. & $\begin{array}{l}\text { Extraversion }+ \\
\text { conscientiousness }+ \text { openness }\end{array}$ & 18 & 19 & 3 & 8 & - & 48 \\
\hline 5. & $\begin{array}{l}\text { Extraversion }+ \text { neoroticism }+ \\
\text { openness }\end{array}$ & 22 & 17 & 2 & - & - & 41 \\
\hline 6. & Agreeableness + openness & 14 & 8 & 1 & 1 & - & 24 \\
\hline & Total & 83 & 89 & 31 & 12 & - & 215 \\
\hline
\end{tabular}


Referring to Table 4, students with personality type 'extraversion, agreeableness, Extraversion + conscientiousness + openness, or agreeableness + openness' are very creative, creative, quite creative, or less creative. The students having personality type 'extraversion + agreeableness + openness, or extraversion + neuroticism + openness' are very creative, creative, or quite creative. Overall, there are 83 very creative students $(38.60 \%)$, 89 creative students $(41.40 \%), 31$ quite creative students $(14.42 \%)$, and 12 less creative students $(5.58 \%)$. No student is uncreative.

Student's flexible or novel answers from their answer sheets as their creative products can be counted and decided in the following ways. One of the problems solved by students is to divide a rectangle into two equal-area parts of unique and various forms. For instance, students divided a rectangle into two equal rectangle area parts; two equal triangle area parts; two equal trapezoidal area parts; two equal two-dimensional area parts shaped zigzag and circular. It means that the student got five correct answer alternatives: rectangle, triangle, trapezoidal, two-dimensional zigzag shape, and two-dimensional circular shaped. The number of student's flexible answer is two, namely: triangle and trapezoidal because their shapes are different from the original one, but not unique. The number of student's novel answer is two, namely: twodimensional zigzag shape, and two-dimensional a circular shape, because they are unique. The rectangle divided into two equal rectangle area parts is not flexible nor novel answer because the shape is the same as the original one.

To search for data and information on student's cognitive knowledge by in-depth interviews, the researchers chose one student from each personality type, as shown in Table 1. The student with personality type 'extraversion' is called Student S1; 'agreeableness' is called Student S2; 'extraversion + agreeableness + openness' is called Student S3; 'extraversion + conscientiousness + openness' is called Student S4; 'extraversion + neuroticism + openness' is called Student S5; and 'agreeableness + openness' is called Student S6.
Based on interview with Student S1, she could draw and design various two-dimensional figures of unique shapes by cutting, folding, and measuring the rectangle into two parts in equal size and area. When the researchers asked her how she ascertained the two parts equal, she just said that if the twodimensional figure is divided into two parts in equal size, they must have equal area; it means she uses her math reasoning. When the researchers asked her how she is able to draw and design the two-dimensional polygon figure, she just said that she used her imagination to create creativity, it means she imagined the relevant things to find creative ideas.

Based on interview results from Student S2, he divided a rectangle into two parts of the unique two-dimensional figure in the equal area by utilizing his intuitions ability. $\mathrm{He}$ had no relevant learning experience previously. He did not also cheat or ask his friends. It means that he solved the problem by his own conscience. Student S3 divided a rectangle into two parts of trapezoidal in the equal area as one of his answers on the answer sheet. He said that a trapezoidal has a pair of facing lines of a parallel position. It means that he really understands the concept of trapezoidal.

Student S4 \& Student S5 divided a rectangle into two parts of the triangle in the equal area as one of their alternative answers. They determined the two-dimensional figure area by using formula. They understand the concept of the triangle by mentioning that one of the angles of the right triangle is 900 . They also divided a rectangle into two parts of the unique two-dimensional figure in the equal area as another answer by using a trial and error system. They also utilized their intuition ability to find creative ideas. Student S6 divided a rectangle into two parts of the two-dimensional figure in the equal area as one of her alternative answers by utilizing her prior knowledge and previous learning experience. According to her, their teacher ever taught and gave a similar problem, meaning that she made an analogy to solve the problem. Referring to student's cognitive knowledge description, the researchers try to summarize them, shown in Table 5. 
Table 5. Student's cognitive knowledge

\begin{tabular}{cl}
\hline No. & \multicolumn{1}{c}{ Student's Cognitive Knowledge } \\
\hline 1. & Draw and design various two-dimentional figures in unique shapes \\
2. & Ascertain the two parts of unique two-dimentional figure of equal area \\
3. & Divide the two-dimentional figures in two equal size parts \\
4. & Reasoning \\
5. & Imagine the relevant things to create creativity and find creative ideas \\
6. & Utilize the intuition ability, prior knowledge and previous learning experience \\
7. & Solve the problem by his own conscience \\
8. & Understand the concept of two-dimentional figures \\
9. & Determine the two-dimentional figures area by using formula \\
10. & Mention the characteristic of two-dimentional figure \\
11. Use trial and error system to determine the unique two-dimentional figure in equal area \\
12. Analogy
\end{tabular}

\section{Discussion}

One of the results and findings of this research is that the students have the creativity and the creative thinking ability to find the novel answers. It is in line with the opinion of Munandar (1999) that creativity is defined as the ability to create new combinations based on the existing data, information, or elements, and find possibly many answers to one problem, where the emphasis is on the quantity, usability, and diversity of answers. Creativity is the ability to reflect the answer originality.

The ability to draw the unique and novel two-dimensional constructed through student's creative ideas at the research findings is also in line with Isaksen's et al. opinion (Grieshober, 2004) that the creative thinking is an idea-building process that emphasizes on the indicators of fluency, flexibility, novelty, and elaboration. Creative thinking tends to the acquisition of insights, approaches, perspectives, or new ways of under-standing one mathematics problem (McGregor, 2007). Martin (2009), an inflexible-thinking individual uneasily changes his/her ideas or views even though he/she knows any contradiction between the belonging of a new idea.

According to Sharp (Briggs \& Davis, 2008), novelty is not idea really new, but new for students. It is also found in this research where the student's answers are only the pentagon, which is actually not two-dimensional, really original from the student's new idea, but the student himself who only drew such two- dimensional in the class. It means that the student's answer has been categorized as a new one if compared to other students' answers. When the student finds this solution to problems with the first time, he has found something new, at least for himself.

Every student has a creative thinking ability, but the level of creative thinking varies. It can be seen by the creation of evidence of certain people in extraordinary technology and knowledge. On the other hand, some people cannot be creative; they have no knowledge or skills at all or only use others' creativity. This state indicates the level or degree of creativity or the creative ability of someone is different. The level of someone's creative thinking can be viewed as a continuum from the lowest to the highest one. If an individual is taken randomly, we can place $\mathrm{him} /$ her in the continuum of the creative thinking level. However, because the number of discreet individuals is considerable, the approach to know the degree of creative thinking is a discrete and hierarchical classification.

Students' personality types influence the ability and level of their creative thinking as the research findings. It is in line with the opinion of Ivcevic and Mayer (2006), stating that personality types can differentiate someone's creative thinking ability. An individual's creativity may differ based on his/her personality differences. Personality can be defined as a psychological attributes system that describes how someone feels, thinks, interacts with the social world, and regulates behavior (Funder, 2001; Mayer, 2005). 
In the last few decades, the Big Five Personality has become the dominant model for describing broad personality traits. The openness of the Big Five Personality is theoretically and empirically defined as a general disposition of creativity.

Creativity is also related to a narrower nature in the area of emotion and motivation, cognition, social expression, and self-regulation. The behavior of emotion and motivation in the creative thinking process offers an opportunity to be creative and can be a source of creative ideas. For example, motivated people intrinsically engage in activities because of their happiness in creating or enjoying the opportunity for expression. Another behavior related to creativity is hypomania, which can enhance creativity, creative potential (e.g., self-perceived creativity), and creative behavior (e.g., involvement in creative activities). The mood increases the awareness, fluency, and flexibility of thinking.

Cognitive knowledge enables someone to generate creativity. One of the student's cognitive knowledge as the research findings is the reasoning ability. The students use their reasoning ability and can be improved by the creative and innovative learning approaches and require them to be more active and skilled in the learning process. The learning approach factor gives a significant influence on the improvement of students' mathematics reasoning ability, either whole or based on the subgroup of students.

The student's ability to determine the two-dimensional area on the research findings is in line with the opinion of Van de Walle, Karp, and Bay-Williams (2008). According to them, a common mistake that often made by students is the using of incorrect-formula to conceptualize the height and pedestal of twodimensional. According to Bahr and Bossé (2008), students must learn mathematics by understanding, actively build new knowledge from previous experience and knowledge. Learning by understanding is important to enabling students to solve the new problems that will inevitably face in the future.

The student's mathematics intuition as the research findings is in line with some opinions which state that the creative thinking in the mathematics subject is a combination of the logical and divergent thinking based on intuition with the indicators of fluency, flexibility, and novelty, one of the creative personal characters is characterized by an intuition ability - an individual needs two mathematical thinking skills, namely: the abilities of intuition and analytic thinking.

\section{Conclusion}

Based on the findings and discussion, the researchers conclude some points of the research. The category of student's creative thinking ability based on the Big Five personality is 'moderate or high'. The level of student's creative thinking based on the Big Five personality is 'very creative, creative, quite creative or less creative'. The student's cognitive knowledge based on the Big Five personality is drawing, designing, ascertaining, dividing, reasoning, analogy, imagining, utilizing, solving, understanding, determining, mentioning and using trial and error.

\section{References}

Alenikov, A. (Ed.). (2002). The future of creativity. Bensenville, IL: Scholastic Testing Press.

Anderson, L. W., Krathwohl, D. R., Airasian, P. W., Cruikshank, K. A., Mayer, R. E., Pintrich, P. R., ... Wittrock, M. C. (2001). A taxonomy for learning, teaching, and assessing: A revision of Bloom's taxonomy of educational objectives. New York, NY: Longman.

Bahr, D. L., \& Bossé, M. J. (2008). The state of balance between procedural knowledge and conceptual understanding in mathematics teacher education. International Journal of Mathematics Teaching and Learning, 1-28. Retrieved from http://hdl.lib.byu.edu/ $1877 / 2880$

Batey, M., \& Furnham, A. (2006). Creativity, intelligence, and personality: A critical review of the scattered lterature. Genetic, Social, and General Psychology Monographs, 132(4), 355-429. https://doi.org/ 10.3200/MONO.132.4.355-430 
Batey, M., Furnham, A., \& Safiullina, X. (2010). Intelligence, general knowledge and personality as predictors of creativity. Learning and Individual Differences, 20(5), 532-535. https://doi. org/10.1016/j.lindif.2010.04.008

Briggs, M., \& Davis, S. (2008). Creative teaching: Mathematics in the early years and primary classroom. London: Routledge.

Carson, S. H., Peterson, J. B., \& Higgins, D. M. (2005). Reliability, validity, and factor structure of the creative achievement questionnaire. Creativity Research Journal, 17(1), 37-50. https:// doi.org/10.1207/s15326934crj1701_4

Choi, J. N. (2004). Individual and contextual predictors of creative performance: The mediating role of psychological processes. Creativity Research Journal, 16(2-3), 187-199. https://doi.org/ 10.1080/10400419.2004.9651452

Cohen, L., Manion, L., \& Morrison, K. (2007). Research methods in education (6th ed.). New York, NY: Routledge.

de Lange, J. (2003). Mathematics for literacy. In The National Council on Education and the Disciplines (Ed.), Quantitative literacy: Why numeracy matters for schools and colleges (pp. 75-89). Retrieved from https://www.maa.org/sites/default/file s/pdf/QL/WhyNumeracyMatters.pdf

Ee, D. N. K., \& Widjaja, W. (2013). Mathematical modelling in the primary school: Elements in teacher education. 5th Redesigning Pedagogy International Conference. Singapore: National Institute of Education.

Feist, J., \& Feist, G. J. (2006). Theories of personality. Boston, MA: McGraw-Hill Education.

Friedman, H. S., \& Schustack, M. W. (Eds.). (2008). The personality reader (2nd ed.). Boston, MA: Allyn and Bacon.

Funder, D. C. (2001). Personality. Annual Review of Psychology, 52(1), 197-221. https://doi.org/10.1146/annurev.psych .52.1.197
Grieshober, W. E. (2004). Continuing a dictionary of creative term and definitions. Buffalo, NY.

Isaksen, S. G., Dorval, K. B., \& Treffinger, D. J. (2000). Creative approaches to problem solving: A framework for change (2nd ed.). Dubuque, IA: Kendall/Hunt.

Ivcevic, Z., \& Mayer, J. D. (2006). Creative types and personality. Imagination, Cognition and Personality, 26(1), 65-86. https://doi.org/10.2190/0615-6262G582-853U

Krathwohl, D. R. (2002). A revision of Bloom's taxonomy: An overview. Theory Into Practice, 41(4), 212-218. https:// doi.org/10.1207/s15430421tip4104_2

Martin, P. N. (2009). Societal transformation and reference services in the academic library: Theoretical foundations for reenvisioning reference. Library Philosophy and Practice, (May), 1-8. Retrieved from https:// digitalcommons.unl.edu/cgi/vi ewcontent. cgi?article $=1265 \&$ context $=$ li bphilprac

Mayer, J. D. (2003). Structural divisions of personality and the classification of traits. Review of General Psychology, 7(4), 381-401. https://doi.org/10.1037/ 1089-2680.7.4.381

Mayer, J. D. (2005). A tale of two visions: Can a new view of personality help integrate psychology? American Psychologist, 60(4), 294-307. https://doi.org/10.1037/ 0003-066X.60.4.294

McGregor, S. L. T. (2007). International Journal of Consumer Studies: Decade review (1997-2006). International Journal of Consumer Studies, 31(1), 2-18. https:/ / doi.org/10.1111/j.1470-6431.2006. 00566.x

Mumford, M. D. (2003). Where have we been, where are we going? Taking stock in creativity research. Creativity Research Journal, 15(2-3), 107-120. https://doi. org/10.1080/10400419.2003.9651403

Munandar, U. (1999). Kreativitas dan keterbakatan, strategi mewnjudkan potensi 
kreatif dan bakat. Jakarta: Gramedia Pustaka Utama.

Neethling, K. (2000). The beyonders. In E. P. Torrance (Ed.), On the edge and keeping on the edge (pp. 153-166). Bensenville, IL: Scholastic Testing Press.

Pehkonen, E., \& Törner, G. (2004). Methodological considerations on investigating teachers' beliefs of mathematics and its teaching. NOMAD - Nordic Studies in Mathematics Education, 9(1), 21-49.

Rahayu, S. (2015). Pembelajaran matematika dengan pendekatan PMRI memang beda. Buletin, VI(February). Retrieved from http://www.pmri.or.id/main.php

Santrock, J. W. (2003). Psychology (7th ed.). New York, NY: McGraw-Hill.

Santrock, J. W. (2007). Child development (11th ed.). New York, NY: McGraw-Hill.

Setiawan, R. (2016). Construct of creative thinking assessment on divergent and convergent ability. International Journal of Advance Research and Innovative Ideas in Education, 2(4), 1034-1041. Retrieved from http://ijariie.com/FormDetails. aspx?MenuScriptId=1904

Setiawan, R. (2017). The influence of income, experience, and academic qualification on the early childhood education teachers' creativity in Semarang, Indonesia. International Journal of Instruction, 10(4), 39-50. https://doi. org/10.12973/iji.2017.1043a

Silvia, P. J. (2008). Another look at creativity and intelligence: Exploring higher-order models and probable confounds.
Personality and Individual Differences, 44(4), 1012-1021. https://doi.org/10.1016/ j.paid.2007.10.027

Siswono, T. T. (2004). Pendekatan pembelajaran matematika. Jakarta: Departemen Pendidikan Nasional Republik Indonesia.

Smith, M. K. (2008). Howard Gardner, multiple intelligences and education. Retrieved from The Encyclopedia of Pedagogy and Informal Education (Infed.org) website: https://infed.org/ mobi/howard-gardner-multipleintelligences-and-education/

Sternberg, R. J. (2012). The assessment of creativity: An investment-based approach. Creativity Research Journal, 24(1), 3-12. https://doi.org/10.1080/ 10400419.2012.652925

Stillman, G. A. (2015). Applications and modelling research in secondary classrooms: What have we learnt? In S. J. Cho (Ed.), Selected regular lectures from the 12th International Congress on Mathematical Education (pp. 791-805). https://doi.org/10.1007/978-3-31917187-6

Van de Walle, J. A., Karp, K. S., \& BayWilliams, J. M. (2008). Elementary and middle school mathematics: Teaching developmentally. Boston, MA: Allyn and Bacon.

Wolfradt, U., \& Pretz, J. E. (2001). Individual differences in creativity: Personality, story writing, and hobbies. European Journal of Personality, 15(4), 297-310. https://doi.org/10.1002/per.409 